\title{
Wanted - a new approach to the life of Jesus
}

\author{
David Seccombe \\ George Whitefield College, Muizenberg \& \\ School for Biblical Studies \& Bible Languages, \\ $\mathrm{PU}$ vir $\mathrm{CHO}$ \\ E-mail: david@gwc.ac.za
}

\begin{abstract}
Wanted - a new approach to the life of Jesus

In 2 Corinthians 3-4 Paul is concerned that post-Easter generations be able to behold the "face" of Jesus. This indicates concern that the story of Jesus be heard. The importance of "giving Jesus a face" is considered from the viewpoint of a pastor. However, the synoptic gospels are not much used in churches today, because of loss of confidence in our ability to know much about the life of Jesus. This is understandable, given Life of Jesus research over the past two centuries. The last 25 years, however, have seen tentative attempts at critical Lives, employing a "Cartesian" approach, doubting everything, seeing what can be proven to be dominical, and constructing a Life on this basis. There is value in this for apologetics, but such Lives cannot compete with the gospels in giving us "the face of Jesus". Nevertheless, Life writing must go on, if only to counter the new wave of Lives, which purport to be historical, but are based on such a selective reading of the gospels, that they are tendentious misrepresentations. A new "canonically-based" approach to the life of Jesus is proposed and described.
\end{abstract}

"Without a doubt it is true to say that the dream of ever writing a biography of Jesus is over". So wrote Joachim Jeremias (1964:12) when form-critical scepticism dominated the scene in New Testament studies. Since the completion of my doctoral studies in 1978 on the rich and poor in the teaching of Jesus (Seccombe, 1983) I have dreamed of writing a life of Jesus. 


\section{The face of Jesus}

The message of the earliest Christians was a man - Jesus Christ - and their mission was to portray him so that others would be drawn to put their trust in him and be saved (Acts 10:34-43). Paul wrote to the Corinthians "We do not preach ourselves, but Jesus Christ as Lord ..." (2 Corinthians 4:5). He went on to say that God, who at creation said, "Let there be light", had now caused to shine in the darkness of human hearts "the light of the knowledge of the glory of God in the face of Jesus Christ". What did it mean that the glory of God had been revealed, and could still be seen "in the face of Jesus Christ"? What could it mean, other than that the beauty and excellence of the invisible God had become visible in the person of Jesus, and that Jesus in some manner continued to be visible? But how could that be after his ascension? Paul as we know spoke often in his letters about the death and resurrection of Jesus, but 2 Corinthians 4 also indicates a fundamental interest in his story, which does not obviously emerge in the medium of epistle (Seccombe, 1999). Is it not suggestive that two of the gospels were written by travelling companions of Paul? Even if one were to follow K.L. Schmidt's claim (1919) that Mark simply strung his gospel together in an artificial order to create the appearance of a story, we are still faced with interest in a person's life, or the important section of it, and it was influential enough to call forth improved versions from the pen of Matthew, Luke, and John.

In fact we need not be reduced to Schmidt's level of skepticism; C.H. Dodd (1932) demonstrated that the synoptic gospels follow an outline of Jesus' career which was part of the Petrine kerygma. When Peter preached to Cornelius he saw fit to rehearse, perhaps in more detail than Acts records, the main events of Jesus' ministry years. It is hard to see how Christianity could have been spread in the first century without a constant retelling of the Jesus story.

According to Paul, "the light of the knowledge of the glory of God is seen in the face of Jesus Christ". It is a curious feature of early Christianity that it had no interest in the physical appearance of Jesus; its focus was on his story. As often as this story was told and his person thus portrayed, God's glory became visible, drawing men and women to put their faith in him. Indeed, according to 2 Corinthians 4, entry into Christian life takes place when God grants someone spiritual enlightenment as he or she is contemplating "the face of Christ". Earlier Paul has said that spiritual transformation (sanctification) occurs when, "with unveiled face" (i.e. with God-given spiritual enlightenment), a person beholds "the glory of the Lord" (2 Corinthians 3:18). The glory of the Lord is the glory of God, which is seen in the face of Jesus. Thus both conversion and sanctification are dependant on the human side, on a person's beholding Jesus, and I am suggesting that the way in which the early Christians helped that process was by telling his story. 
My own concern to write about the life of Jesus arose from two sources: first from my fascination with his human career, born of three years' close study of his background and teaching, and secondly from preaching. Moving from postgraduate research to leadership of a parish church, I experienced rapid congregational growth from 1979-1992. Every Sunday new faces appeared, who often turned out to be people who had rarely if ever been to church before, and were reopening in their own minds the question of whether there is an answer in Christianity to the insecurity, impersonalness and meaninglessness of modern life. They were not like the seekers of one hundred, or fifty or even thirty years ago. Their choice was not simply between religion and irreligion; they had a variety of religious and philosophical options from which to choose. One could not simply say "The Bible says!", for they knew there were other holy books. One could no longer say, "You should come to church!" for the church had been endlessly discredited in their eyes, and in any case, they were there, asking why they should stay.

What shall we show them? A warm and caring community, and perhaps counter for a time the loneliness and alienation of some? I was constantly startled by the number of people appearing in church who had been hurt by others and were desperately searching for something genuinely human. Or we can present to them a Christian "philosophy of life" and provide a satisfying "world view" to those who are confused about the meaning of life. In a congregation with a large number of students and academics, this was particularly important and effective. Or we can present a Christian way of life to those who are sickened by the moral confusion around them. In a church of young families this was a special concern.

But at the base of anything we wish to declare as Christian, stands Jesus. He is the "Lord" who calls the caring community into being and sustains its caringness. He is the centre of a Christian philosophy of life. He is the authority and the motive for a Christian way of life. But is he real? The question of truth matters to people, and it should. Certainly there are those who are happy to lap up the benefits without inquiring into the basis, but not many. There are also costs and demands, and who will face these unless he knows that they stem from what is true. It is not enough to give people a warm community, and a satisfying view of life, and a health-giving moral outlook. If we want them to be Christian, we must give them Jesus. He is the source of these things, and can give them the roots of these things in themselves. But of course he also gives much more. For meeting people's felt needs is not his only role; he had and has his own agenda, "the kingdom of God".

Christian identity and integrity depends on our being able to affirm our connection with Jesus of Nazareth, the "founder of Christianity", as Dodd called him (1971). Christian action in the church or in society depends for its christianness on its being able to establish a genuine connection with Jesus and 
his programme. So I came to see that my most important task was to show people Jesus, to let his "face" be seen, and that meant telling his story.

\section{A portrait in a glass case}

Despite the accessibility of the gospels, the "face" of Jesus for most of this century has been marred beyond recognition if it is visible at all. The scholarly world suffered a massive loss of confidence in the possibility of knowing anything much about the person of Jesus, which filtered down into the churches and on into the general populace. I recall hearing a Cambridge preacher tell his congregation that only four things could be known with any certainty about Jesus: that he was a Galilean, that he was born in Nazareth (sic), that he was baptized by John, and that he was crucified by the Romans. Even where form criticism was not taken to such extremes, the insistence that the gospels had distorted Jesus to serve the needs of the early church meant looking at his picture at the back of a very dirty glass case.

Preachers of all persuasions find the synoptic gospels most uncomfortable to work with, except where they lend themselves to moral lessons. In one church I attended for several years, sermons on the gospels, when they featured at all, consisted of an explanation of why this or that passage did not contradict the doctrine of justification by faith - even though it appeared to! We were told what it didn't mean, but left stranded as to what its message actually was. A woman attending one of my university extension courses on the life of Jesus identified herself as a church person, but added as her reason for being at the course, "We don't hear much about Jesus in the church".

In the scholarly world one manifestation of this nervousness about the historical Jesus was the tiny number of Lives written in the first three quarters of the century compared with the absolute flood in the century before. What was it that brought about this loss of nerve?

\section{The rise and fall of the life of Jesus}

Schweitzer (1998) fixed on Reimarus' Concerning the Intention of Jesus and His Followers (1778) as the beginning of the 19th century Life-of-Jesus movement, and most historians of New Testament scholarship have agreed. Reimarus' terse, but convincing presentation of a Jesus, who, seeking acceptance in a straightforward political manner as Israel's political messiah, suffered defeat and disillusionment on the cross, was a shocking challenge to Christian faith, particularly when it seemed that he was basing his reconstruction on the very evidence which the gospels supplied. The question arose whether there might not be a discrepancy between the Jesus the gospels sought to portray, in which the Church placed its faith, and the historical (real) Jesus able to be recovered by the gospel critic. 
There followed the veritable gold-rush-like attempt to uncover the real Jesus, familiar to us from Schweitzer's masterly survey of 1906 (1998). Rationalist lives of Jesus, fictitious, mythological, liberal, traditional and consistenteschatological is the way he classifies them. In his autobiography (1966:41-42) Schweitzer tells how he made a huge pile of Lives in the centre of his room and then distributed them to separate heaps corresponding to his classifications; no one was allowed to touch the piles until each chapter was completed. With incisive wit, but also with great appreciation he pinpoints their sillinesses and insights. For contrary to the common perception, Schweitzer was not critical of the attempt to write the life of Jesus; he saw it as a great flowering of the human spirit. Even the fictitious Lives gain his approval to the extent that they sought the inner connection of cause and effect in the life of Jesus: "instead of contenting themselves with the simple reproduction of the successive sections of the Gospel narrative, [they] endeavoured to grasp the inner connection of cause and effect in the events and experiences of the life of Jesus. Since they found no such connection indicated in the Gospels, they had to supply it for themselves" (Schweitzer, 1998:38). Schweitzer, too, was determined to find that "inner connection" - the aim or quest of the historical Jesus - and following on the work of Johannes Weiss, believed that he had succeeded. It is something of a paradox that he is often seen as having finally discredited the attempt to write the life of Jesus. That was not how he understood his work, for although it is true that he spends the greater part of his book subjecting much of the Life-ofJesus movement to acid criticism, his final conclusions are eminently positive, both of the value of the whole enterprise and of the results to which it had led him personally. The English title of Schweitzer's book is frequently misunderstood - "the quest of the historical Jesus" has become a term to describe our quest to rediscover the Jesus of history; Schweitzer's great interest was to discover what Jesus' quest had been, and he was sure he had succeeded.

Schweitzer's solution is well-known. Jesus believed that the kingdom of God was about to dawn. In a very short time God would wrench open the heavens and intervene in the world of human affairs to reveal him (Jesus) as the heavenly Son of Man, who would rule forever over God's people. When he sent out his twelve disciples on their mission he told them that all this would take place before their return. When it did not, he was forced to the realization that God wanted him first to die for the people's sins; only with this accomplished, would the kingdom come. Jesus then set out to bring about his own death in Jerusalem. On the cross, feeling abandoned by God and realizing that what he had believed was a terrible mistake, Jesus cried in despair "My God, my God, why have you forsaken me?" and died. That is where, in Schweitzer's reconstruction, it all ended. He adds a brief epilogue, but for all its fine words, it is only a funeral oration over a dead hero. He makes it perfectly clear that Christianity insofar as it involves faith in a God who intervenes in human history is no longer possible. Jesus took that belief to its logical conclusion and disproved it. The early 
Christians drew precisely the opposite conclusion, because they were convinced the story did not end there.

Schweitzer then began to study medicine and devoted the rest of his life to the building of an earthly humanitarian kingdom, though at the end he himself had to face the very real probability that, with the advent of the nuclear age, his own quest too might end with a cry of dereliction.

Schweitzer's conclusions were so negative and so obviously destructive of Christian faith that he unnerved the whole inquiry into the life of Jesus, and cast a shadow over his person for most of the twentieth century. Not only had the quest of Jesus been found to be mistaken, but increasingly the quest for Jesus was felt to be mistaken and unnecessary and impossible. The flood of Lives subsided to barely a trickle for most of the century.

\section{Searching for a new approach}

Almost simultaneously with Schweitzer's attempt at a definitive solution to the Jesus question, Martin Kähler raised a protest against the whole enterprise: "I regard the entire Life-of-Jesus movement as a blind alley" (Kähler, 1964:46). Kähler contended that what modern authors were presenting as the historical Jesus was a product of human creativity. We have no sources for a biography of Jesus, nor any adequate analogy to a sinless person. The biographer is forced to fill the gaps from his own imagination and the result is as much a dogmatic formation as the gospels are accused of being. It is unacceptable to suppose that the modern biographer could be in a better position to know Jesus than those who lived before the era of scientific criticism. Kähler (1964:71) argues that the resurrection brought the life of Jesus to an end. The result of his life was the faith of the disciples and the preaching of Christ: "We should attempt to do only one thing in our pulpits, namely, to present to our hearers these old, often heard, 'outdated stories' - just as they stand, yet freshly and as if heard for the first time". How often has a believing Christian sighed similar words. Kähler's whole essay breathes a deep faith seeking to defend the gospel against the destructiveness of the Life-of-Jesus movement. However, although he does not question that the New Testament portrayal of Jesus is essentially true, his seeming acceptance of the dubious historical worth of the gospels forces him to a radical cleavage of history from preaching. He could hardly have welcomed it, but the direction his thoughts were to lead was to a denial of any relevance of the real Jesus to Christian faith and preaching. This was the very thing he was fighting to preserve.

Rudolf Bultmann took Kähler's lead to such an extreme that Jesus of Nazareth effectively disappeared behind the church's preaching of Christ. But Bultmann's denial of the recoverability of the historical Jesus, his focus on the gospels as the faith literature of the early church with little bearing on the real Jesus, and his 
flight into a demythologized Christianity were also responses to Schweitzer, motivated perhaps not so much by the uncertainties of the source documents, as by the fear that too close an inquiry into the historical Jesus would reveal a deluded fanatic (Schwärmer). Bultmann's programme answered exactly to Schweitzer's call for a new Christianity without any belief in a God who intervenes in the world (Schweitzer, 1998:358, 396ff; 1966:65ff).

Disfavour with Life writing, however, by no means meant the cessation of scholarly attention to the history of Jesus. Immense effort was expended in trying to distinguish authentic Jesus traditions from the overlays of the early church. Detailed attention to the way in which Jesus' preached the kingdom as something present in his ministry led Dodd (1936) to expound his view of "realized eschatology" in fundamental opposition to Schweitzer's solution. Jeremias, Kümmel and Ladd sought to do justice to both present and future eschatology in the sayings of Jesus. Great advances were made in understanding the Jewish and Hellenistic background to the New Testament. Sensitivity to the redactional style of the different evangelists grew. There were even a few attempts at Lives, the later ones witness to a growing dissatisfaction with the extreme scepticism of the form-critical period and to the irrepressibility of questioning about the shape of Jesus' earthly ministry.

\section{A tentative new quest}

Interestingly it was an essay of a disciple of Bultmann (Käsemann, 1953), which began what has been named "the new quest of the historical Jesus". The scepticism about the gospels inherited from Bultmann remains, but there is a new desire to discover enough of the Jesus of history to justify speaking of Christian faith as faith in Jesus. Käsemann saw in the irreducible minimum of Jesus' teachings the reflection of an authority which was so unique, that it must reflect the reality of what Jesus was for people of his own time, and which therefore establishes some continuity between Jesus' message and the gospel of the post-Easter church. The most important fruit of this invitation to go further with the "Jesus of history" was Günther Bornkamm's Jesus of Nazareth published in 1956. Bornkamm maintains great reserve about the amount of the gospels which are really about the earthly Jesus, but sees in the many stories about Jesus similar features recurring by which the historical Jesus can be recognized. From these he develops an attractive portrait of Jesus as a person of unique authority, who was able to make the reality of God immediately present to people. What is lacking in Bornkamm is a real attempt to grapple with the meaning of Jesus' mission from Jesus' own point of view. He thinks that Jesus did not claim to be Messiah, but acted messianically, but as to what that meant for Jesus, he is silent, regarding the early church as author of everything which might enable the question to be answered. Like Bultmann's Jesus (1951), it is in the end, an exposition of some of Jesus' teachings, vastly improved by 
recognition that only a man whose sense of authority exceeded what is normally human, could have uttered such teachings, and by the inclusion of a portrait of Jesus based on the bulk impression of the many stories in the gospels. We are left mystified about the real meaning of Jesus' ministry despite the fact that Bornkamm is open and warm in affirming the reality of the resurrection. One might characterize Käsemann's and Bornkamm's approach as essentially Cartesian: doubt everything and then see what can be established on the basis of rigorous historical reasoning. A feature of such studies is a much reduced historical framework for Jesus' ministry and a concentration on certain themes, such as teaching, parables, exorcisms, miracles and controversy. A significant work from the English side which essentially belongs to this genre is C.H. Dodd's The Founder of Christianity (1971). Its author came to the subject at the conclusion of a long and distinguished life of detailed critical study of all aspects of the history of early Christianity and its literature, and writes completely aware of every challenge that has been laid at every point of the gospel tradition, and as one who shares the critical stance. The book testifies to how much of the original Jesus can still emerge from such demanding scrutiny. It is unequivocal in its affirmation that Jesus saw himself as Messiah. Nevertheless it leaves us a long way short of the Jesus of the gospels.

\section{The old quest renewed}

Something happened in the seventies. Perhaps it was the growing accumulation of background studies which invited application to a Life of Jesus. Perhaps it was the realization that the scepticism of the form-critical era was unreasonable and unjustified. Perhaps it was a growing curiosity about a significant person, who no one doubted lived, whose background was recoverable, and whose story was known, albeit in a suspect form, from several of his contemporaries. Perhaps it is impossible for ever long to push down an inquiry of such importance to human beings. Much of the nineteenth-century ferment bears witness to an almost unquestioned assumption of Western culture that Jesus was the ideal of human being.

This feeling appears to have been shared by those inside and outside of the church. It led to the attempt to rescue Jesus from the church and reinstate him as the epitome of whatever understanding of human life any author held. So the nineteenth century gave us rationalist Jesus's, and Marxist, capitalist, liberal, Essene and mystical Jesus's. It was the recognition of this subjectivity that gave rise to the jibe that Life-of-Jesus scholars were like men peering down a deep well trying to see the face at the bottom and succeeding only in seeing their own reflection. Since the 1970's there has been an increasing flow of Lives or studies of the historical Jesus of a similar ilk: political revolutionary (Pike \& Kennedy, 1972), charismatic wonder worker (Vermes, 1973), man of the Spirit (Borg, 1987), peasant Jewish cynic (Crossan, 1991), Essene renegade (Thiering, 1992), grass-roots social reformer (Horsley, 1993), and so on. Many of these studies, 
like their 19th century forebears, rely for their success on a close selection of what material they will allow as authentic. Robert Funk, founder of the Jesus Seminar, in Honest to Jesus (1996) happily declares his hostility to the church and, on the basis of the small proportion of the Jesus tradition which he deems authentic, recovers a Jesus whom he characterizes as a "comic savant", a poet who overturned conventional thinking with humour and troubling insight (Funk, 1996:1-14, 158-162). Funk is candid in his rejection of any of the gospel material that is at variance with his characterization: "It is unthinkable, in view of the parables and aphorisms, that Jesus said many of the things he is reported to have said" (162). One wonders about the value of a Life based on such a limited selection of the material, other than to allow an author to pit a new Jesus against traditional Christianity and to bolster his own life ideals. The result in Funk's case, and this holds true for most of the characterizations which have arisen from similar methodologies in the past 30 years, does not yield a figure many people are following today, nor would conceivably have followed in the past. For an account of Jesus to be credible it must at least establish why people followed him in the numbers they did before his death and afterwards. It is here that the so-called Third Quest is proceeding in the right direction.

\section{The third quest}

N.T. Wright lists twenty scholars, beginning with G.B. Caird in 1965, who belong roughly to what he calls "the Third Quest" (Wright, 1996:84). The chief characteristic of this approach is a renewal of Schweitzer's attempt to explain the intention of Jesus, and thus to understand his whole ministry, against the background of first-century Jewish hopes for the future. The Jewish hope for a great future national restoration in which the promises of the Old Testament prophets would be fulfilled must necessarily have conditioned the way Jesus' contemporaries heard his message of the kingdom, and there is every indication that Jesus intended this. Wright's recent magisterial study, Jesus and the Victory of God (1996), while not a life, nonetheless shows that the attempt to reach an understanding of Jesus' ministry without jettisoning a large proportion of the gospel tradition is not only still alive, but within reach. One of the authors in his list, E.P. Sanders, has in fact written a modest Life, though it is tentative or negative on many fundamental aspects of the gospel portraits. Sanders thinks Jesus probably did not see himself as Messiah, for example, though saw himself in a unique relationship with God (his “viceroy") (Sanders, 1993:238-248).

\section{The enlightenment project}

It is possible to see the history of the Life of Jesus movement as ongoing stages in an enlightenment project. In Cartesian manner one begins by doubting everything. This may be because one does doubt, as in the case of the sceptic, or because we choose, for whatever reason, to go through the exercise of 
hypothetical doubt, in the case of the believer. The attempt is then made to see how much can be reasonably proven. In the case of an historical inquiry, where by the nature of things absolute proof is not possible, this entails setting the bar of reasonable proof at some agreed level. We then proceed methodically to agreed determine which parts of the Jesus tradition - which actions, and which sayings - can be reasonably demonstrated to go back to Jesus himself. The next step is to construct an account of his life and teaching utilizing only these building blocks. Bornkamm, Dodd and Sanders are all representatives of this procedure. Another is John P. Meier. His massive, as yet unfinished study, A Marginal Jew $(1991,1994)$ painstakingly examines each part of the tradition with the "modest aim" of determining what may with some measure of certainty be said to go back to Jesus. Meier (1991:31) makes clear, however, that "the historical Jesus is not the real Jesus" "Of its very nature this quest can reconstruct only fragments of a mosaic, the faint outline of a faded fresco that allows of many interpretations" (1991:25). This takes us back to Kähler's protest.

What value is such an enterprise to Christians and the Church? It has considerable value to the apologete, and therefore to the preacher, to know that this or that aspect of the tradition may be demonstrated to be dominical or to square with other known facts. It is helpful to know that John's Pool of Bethesda has been identified and existed, when once it was thought to be a Johannine fiction. It is good to learn that Nazareth is now known from inscriptional evidence, and was not invented on the basis of Old Testament prophecies. It is worthwhile being sure that Jesus was a remarkable exorcist, because his opponents tried to explain this away by accusing him of being in league with the devil. It would also be of immense interest to Christians to know that what can reasonably be proven about Jesus is consistent with the early Christian interpretation of his mission. It was to prove that it was not that motivated Reimarus, Strauss, Schweitzer, Vermes, Funk and a host of others, and caused others in turn to dispute their interpretations. We should never overlook the fact that running through this whole enterprise is a battle against and for the historic Christian faith.

Having said this, I want to indicate a problem for the Christian in the general direction of Life-of-Jesus reconstructions. If our portrayal of the life of Jesus must be limited to those pieces of the tradition that have succeeded in vaulting whatever bar of scepticism we may have erected, it will have very little value for faith. We will find ourselves in the position I described at the beginning, of a Jesus whose characteristics and story can barely be seen. For us who are two thousand years removed, can the "face of Jesus" only ever be "a faded fresco"?

It depends, of course, on how we view the gospels. If we accept them as honest testimonies of men who knew the larger story of which they were telling part, then we have four portraits of his "face" (three if we were doubtful about one of 
them). In spite of the wishful claims of some, two centuries of gospel study have not rendered such a stance unreasonable. To the contrary, so much, which at one time or another was thought to be fatal to the gospels' claim to historical respect, has been shown on further research to stand. Even the Fourth Gospel, which once was dismissed as virtually a work of fiction, is now defended as a historically credible source (Robinson, 1985; Hengel, 1989).

There is a further consideration. Most of the gospel tradition cannot be verified. But as Heinz Schürmann once said, "What cannot be proven to have happened did not therefore not happen". We may not be able to prove that the mission of the twelve occurred. That does not mean it did not. If it happened and we ignore it, our reconstruction of Jesus' ministry is going to be seriously flawed. Most historical knowledge is of this kind, resting on some kind of testimony, and only open to verification at certain points. This means that a Life based only on verifiably dominical tradition is destined to be a distortion. Unless the gospels are total fiction, their picture of Jesus is going to be more accurate than one extrapolated from a few verifiable sayings and incidents, for the simple reason that they contain so much else that probably happened. If they are so flawed that almost nothing they say is true then the Life-of-Jesus quest is doomed anyway by lack of any reliable knowledge. So, although it may be a very useful exercise to determine how much of the gospel tradition can with a high level of historical certainty be traced back to Jesus, the additional step of erecting a portrait of the man on this reduced basis and imagining it to be superior to that of the gospels is highly questionable. Thus we are pushed back to the gospels for our picture of Jesus.

Does this mean we must return to Kähler's position, then? Must we preach the canonical Jesus and regard the Life-of-Jesus quest as a blind alley? I do not think so. It lacks integrity to entertain great doubts about the historical accuracy of the gospels, and yet believe and preach them as though they were fact. Scholar, preacher and reading believer will always be sensitive to challenges to the truthfulness of this or that part of the gospel record and particularly sensitive to any representation of Jesus which claims to make better sense of the evidence than that of the gospels. To that extent the believer who is confident of the gospels' testimony will be watching the development of the Life-of-Jesus quest in the expectation that increasing knowledge of the background, further archeological studies, greater general historical understanding, increased understanding of Greek, Hebrew and Aramaic, and better exegesis will in the end yield a picture in recognizable harmony with that of the New Testament. But I wish to argue for something more.

\section{Proposal for a new approach}

In proposing a new approach, I am not suggesting abandoning other approaches. I have already set out what I see as the value for the apologete and the preacher 
of the Enlightenment project, as well as some of its shortcomings. Is there not a place, though, for what we might call a canonically-based life of Jesus? The gospels give us four portraits, four angles on their subject, the man Jesus. Is there not the possibility and place for a composite picture, a fifth angle, constructed on the basis of confidence that each of the four gospel writers was a reasonable man, in touch with the foundational story, and telling it from his own standpoint?

What I am proposing is more than a harmony of the gospels. One of the problems of the gospels is the difficulty of understanding them for people removed from their political, social, cultural, linguistic and religious background. A canonically-based Life would need to employ the best knowledge from all these areas as means, if I may extend the analogy, to illuminate the portrait.

There are also questions which are raised by the gospels that are not answerable from one gospel. The critical question of Jesus' intention is a case in point. Presumably all the gospel writers knew the answer; it was just not part of their limited project to explain it in detail. Indeed they may not have needed to; to readers who shared their background, it might have been quite plain what various parts of the story implied, even if it is hidden from us. A canonicallybased life of Jesus need not be simply a rearrangement of gospel pericopes; it needs to struggle with meaning, and attempt to integrate difficult pieces into a coherent whole.

One of the attractions of the gospels to researchers is that they contain so many unsolved mysteries. At one level they are like a detective novel in the way they drop clues of something momentous on every page. Unlike a novel, however, they do not come to a neat conclusion which shows how everything fits together into a coherent picture, or at least it is not apparent to the modern reader. The ministry of Jesus is a puzzle. He did and said many things which do not fit neatly into our understanding of him and his mission. So much of what he said and did does not fit neatly into traditional Christian interpretation. This shows that we do not yet fully understand his quest. Indeed, it is orthodox Christianity's lack of a coherent understanding of Jesus' mission which in part has brought forth the Life-of-Jesus movement, and which makes it so vital to us. One of the things which convinces me that the gospels are really telling us of Jesus, and not just about the beliefs of the gospel writers, is that so much of what they relate raises questions which they do not attempt to answer. Why, for example did Jesus seek baptism from John? Why did he undertake a forty day fast? Why did he never fast again until the night of his betrayal? Why did he baptize in the early days and then cease baptizing? Why did he say that men of violence were seizing the kingdom? Why did he say the kingdom was present, and at other times imply it was still in the future? The list of not easily answered questions goes on and on. At the risk of stretching the metaphor, it is as though 
in a number of different portraits of a great man some scars are evident, though no one tells how they got there. The person who views these portraits cannot help asking how the subject came to have these marks. In the story of Jesus the "scars" are many and they do not all relate to matters which are incidental.

A canonically-based Life will also be something of a harmony. Gospel harmonies have been tried in the past and found wanting; indeed have been declared an impossibility. But we need to understand why this was so. When the gospels were approached as chronologically-based biographical histories and the attempt made to dove-tail them, so many contradictions emerged that scholarship retreated from the attempt. However, New Testament scholarship today has a greater awareness of the nature of the gospels. We do not need to make the mistake of thinking that everything happened in the order the gospels present it. The insights of form, redaction, narrative and historical criticism allow us to view the gospels as a fusing of historical, theological (meaning), and literary dimensions. The evangelists deliberately included a great deal of material in non-chronological sequences, which are not therefore without value to a Life. The healing of the leper is related in three different contexts in the synoptics. It hardly matters to know at exactly which point in Jesus' ministry it took place, yet it is of great significance that it happened sometime. Accordingly, it has been a marked feature of recent Lives (Bornkamm, 1973; Dodd, 1971; Sanders, 1993; Stein, 1996) to depict most of Jesus' ministry synchronically, with chapters, for example, on Jesus as Teacher, Miracle Worker, Friend of Sinners, Controversialist and so on.

However, this can be overdone; because we detect thematic elements, does not mean nothing in the gospels can be shown to be in chronological sequence. Matthew and Luke both utilize the story of the leper in theological contexts (Matthew as a counterfoil to the sense of guilt awakened by the Sermon on the Mount, Luke to highlight Jesus' power to cleanse/forgive at the moment of Peter's awareness of sin on the occasion of his call). Mark, however, has placed it in an important chronological sequence: it was part of the reason Jesus took to preaching in the countryside early in his Galilean ministry.

Growing understanding of the nature of the gospels is leading to increasing awareness among some scholars that the traditional distaste of harmonization in gospel studies has been exaggerated (Wright, 1993:113-115). Dogmatically rejecting attempts at harmonization makes it impossible to approach the question of history, since historical knowledge is chiefly gained by a process of critical harmonization. Normally the harmonization of different accounts of an event (or person) is the path to a greater and truer knowledge than is given by any report taken on its own. If various records exist relating to a particular event that needs investigation the general procedure is to see what harmony exists between them and also how they harmonize with other known facts. Of course problems can arise and usually do. One or all of the reports may contain false information, or 
there may be complexities in the event or inadequacies in the reports which make it difficult to get at the truth. Yet even here it is the disagreements or disharmonies which allow us to pinpoint the problem areas and perhaps unmask a false report, or correct an untrue interpretation or assumption.

There is such a thing as forced harmonization, and it is this that has made it a dirty word for some. Christians have an obvious interest in the integrity of the gospels and have sometimes resorted to silly harmonizations, which do nothing to further their cause. There is wisdom in the remarks with which Vincent Taylor (1954:222) prefaced a discussion of the resurrection:

Well meant attempts to harmonize the narratives by the aid of ingenious, but not convincing, speculations, only serve to bring historical criticism into disrepute, and it is wise neither to attempt them nor to entertain them.

A canonically based Life, such as I am advocating, will obviously form something of a test-case for a new harmonistic approach to the gospels. If the project collapses into contradictions, as did the 19th century attempt, or can only be prosecuted with forced and silly harmonizations, it may become evident that the working hypothesis is erroneous. If, however, a coherent and convincing picture emerges, it will encourage us to think we are going in the right direction.

\section{Why write lives?}

Why try to write a history of Jesus? Am I not virtually advocating that we try to write a fifth gospel? In a sense I am, and in a sense it is an appropriate enterprise for any Christian. Each of us, having seen for ourselves the "face" of Jesus in the manifold form in which it is presented in the New Testament, will want to portray for others what he himself has seen and what he finds compelling. I do not mean that all should literally write a book about it, but that each in his or her own medium of expression will want to make the attempt to render a "portrait". This indeed is how the four gospels originally came into being, and Christians ever since have been retelling the story in their own words, some through books, others through drama, some from the pulpit, and others over the back fence. In the first instance writing a Life is simply a way of talking about the Jesus we find so compelling. New Testament scholars have a special duty, however, because they have the detailed knowledge of background and the exegetical tools hopefully to form a more authoritative and accurate picture.

Most Christians have in their minds a composite picture of Jesus, which has been formed from their reading of the gospels, Sunday School, sermons, movies and books. It is frequently something of a jumble, however, with little precision or proportion such as comes with a knowledge of the background and of the distinctive contributions of the four evangelists. As Theissen and Merz (1998:vii) put it: "Many people today are at a loss if they become engaged in an argument and have to explain what we know of the historical Jesus, what we can 
only conjecture, and what we cannot know". Most glaringly absent is any sense of how the various events of the ministry years hang together and what they mean. The central concept of the kingdom of God means little to many Christians. Once again the gospel scholar's calling is to provide this clarification and I am suggesting a canonically-based Life is one way of doing this.

I have several times spoken of the gospels as portraits, and suggested that a canonically-based Life be seen in the same way. This is an analogy I first heard from C.F.D. Moule, in a Cambridge lecture. R.T. France uses the same idea in the subtitle of his book, The Man they Crucified - A Portrait of Jesus (1975). We have four gospels each of which gives us, not an ordered history of Jesus and his ministry, but something more like a portrait. Each of the portraits is different, but they are unmistakably portraits of the one man. Taken separately "the face" which emerges from each gospel writer's work is compelling to the point of creating and sustaining faith. But it is inevitable that human minds will fuse these pictures into one, will create from them a fifth portrait. It is desirable that what results is a true representation, and one that even contains more than is easily visible in the originals. The result of such an attempt will always be provisional. It can never stand beside the canonical portraits of Matthew, Mark, Luke and John, for they are source and it is synthesis, they are canon and it is copy, they are revelation and it is an attempt to understand revelation. But faith must always be seeking to understand itself.

There is a further reason why we must continue the struggle to write accurate Lives. The enemies of Christianity will continue to produce their portraits and call them history. We are heirs today of two centuries of sceptical scrutiny of the gospels and cannot ignore the question of what really happened, and whether the "face" which the gospels portray is a reasonable representation of Jesus of Nazareth, or not perhaps something more akin to the imaginative fancies of modern-day religious artists, as the sceptics wish to convince us. It is up to gospel scholars to write better history and expose the distortions. I suggest that a canonically-based Life is one way of doing this. The justification of such a reconstruction will be its greater coherence, internal consistency, and agreement with other knowledge of the times, than those which ignore or distort large parts of the gospels' witness.

\section{Challenges and considerations for a canonically-based life of Jesus}

\subsection{The gospels as sources}

By advocating a canonically-based approach to the Life of Jesus I do not wish to suggest we can ignore the question of the reliability of the gospels' traditions. There is hardly a sentence in the gospels which has not been questioned and doubted. We cannot sidestep this, even when we may give the benefit of a doubt 
to the evangelist. The gospel material falls into four categories: that for which there is good evidence to vouch for its authenticity, that which is likely to be correct though it has not been proven, that which has not been disproved though it is widely doubted, and that which is regarded as disproved. It is important in building a picture of Jesus' ministry that we approach these different kinds of material with due sensitivity. A great deal more care will be required, for example, for including the mission of the seventy two in our picture than for the mission of the twelve. Things like John's description of a temple cleansing at the outset of Jesus' ministry will present a challenge of a different order to that of Jesus' triumphal entry in the last week.

\subsection{Chronology and framework}

In any history the question of chronology has its place. If we are dealing with real events, we must expect them to respect what A.E. Harvey (1982) calls "the constraints of history" and conform to the laws of time and space. If the gospels say Jesus was crucified by Pilate, it is important to see that other indications also place him in the time of Pilate's prefecture. There is a well-known discrepancy between John and Mark's timing of Jesus' crucifixion; he cannot have been on the cross at 9 am if Pilate was still trying him at noon (Mark 15:25; John 19:14). A Life which declines to contend with the nitty gritty of places and dates and times cannot pretend to be history.

More important than the absolute chronology of Jesus' appearance, ministry and death, however, is the ordering of certain key events within his ministry. It does not make much difference to the story whether he was crucified in AD 30 or 33 . It is more important to know whether the ministry lasted one, two, three or four years. There is a tendency in recent lives to give very little attention to the sequence of Jesus' ministry between his baptism and the last week. John Meier (1994:237) expresses it with his usual succinctness: “... we must constantly remind ourselves of a basic rule, between Jesus' baptism and the last week of his life, there is no before and after. The time frame and plot line of each evangelist is his own creation". There is no such rule, yet even an evangelical writer like Robert Stein (1996:49), who assumes that the gospels are "authentic unless proven inauthentic", places nothing between the call of Jesus' disciples and his triumphal entry except the complex of events surrounding Peter's Caesarea Philippi confession. This seems to me a fault. What are we to do with Mark's first appearance of Jesus in the Capernaum synagogue, the changing mode of his teaching in Galilee, the selection of the twelve (as distinct from their call to be disciples), the Sermon on the Mount, the mission of the twelve, John the Baptist's inquiry about Jesus, the execution of John and its effects, the feeding of the 5000 , Jesus' woes over Galilean towns, the mission of the seventy two and so on? One of the challenges to any writer of a Life is to determine how much of the gospel material can be legitimately placed in historical sequence and whether there is any significance in this order. I have already noted that 
some material is ordered thematically. We need to be sensitive to what the gospel writers are doing, but not gratuitously throw away valuable indications of a ministry of a particular shape, which may lead us to greater understanding of Jesus' aims and strategies.

\subsection{The teachings of Jesus}

In all of the gospels Jesus is depicted as a teacher and each seeks to give some selection of his teaching. Matthew and Luke evidently both felt the lack of teaching material in Mark and supplemented it, each in his own way. The teaching is different in content and form to anything else we find in the rest of the New Testament or in the early church - so it has a very good claim to have originated with Jesus. This judgement has been complicated by the form-critical movement which saw the teaching as so modified by the early church, if not actually invented, that it became a tortuous business arguing the case for the authenticity of any saying or piece of teaching. Rudolf Bultmann (1931) sifted the entirety of Jesus' recorded sayings and not much escaped as being dominical. Recently the Jesus Seminar has developed a procedure of voting on each saying, parable, and discourse, and has published its findings in a "red letter" edition of the five gospels (Thomas is included) (Funk \& Hoover, 1996). Red sayings ("Jesus undoubtedly said this or something very like it") are rare: only one sentence of Mark (12:17), and eight pieces in Luke, one of which is a single word. Pink passages ("Jesus probably said something like this") are also conspicuously fewer than those that are judged probably or certainly not to belong to Jesus (I count 52 lines of pink material in Mark of which 27 lines are in the parables of Mark 4). I suppose one can be as sceptical as one chooses, but it leaves me asking why Jesus was remembered as a teacher, if the early church bothered to remember so little of what he said. What could they have thought they were doing when they were inventing teachings to place in his mouth? One must question on what basis such wholesale cutting of the tradition is undertaken, be it by Bultmann or the Jesus Seminar, and whether the image of a preferred Jesus does not lay hidden in the background, to emerge as "the historical Jesus" at the end of a totally circular process. Bultmann was at least consistent in denying at the end of his cutting that we could know anything much about Jesus; the Jesus Seminar wants to pare the tradition back almost to nothing and still discover a coherent Jesus at the end.

Ideally a canonically-based Life of Jesus will seek to account for all the sayings and teachings which are attributed to Jesus. Even if some of the recorded sayings were proved not to be genuine, the mistakes made in proceeding this way will in the end be less than those which result from giving the scholar liberty to pick and choose. It is not necessary to adopt the extreme position that we are dealing with the ipsissima verba of Jesus. Many of the sayings will have had a history of use after Jesus, before they were incorporated into a gospel. One 
should not exaggerate the significance of this, however. The canonical gospels (unlike Thomas and the apocryphal gospels) were all written within the memory generation of Jesus' first listeners. There may have been tendencies to modification, but there were also correctional factors. The teachings of the rabbis were treasured and remembered. There is every reason for thinking Jesus' were too (Riesner, 1981:408-453; 1991:185-210).

Obviously our texts are Greek and modifications may have been made by the evangelists as they fitted sayings and discourse to their story. Whether it is possible to separate the dominical component from any saying and identify the redaction is doubtful, in my opinion. A teaching may be entirely in the language and style of the evangelist and yet faithfully represent the teaching of the master. We are quite comfortable today with the difference between quoted speech and indirect reporting. The issue is not whether Jesus said the exact words, but whether the evangelists have fairly conveyed his meaning. It is a futile exercise in my opinion to shred a pericope and think we can reconstruct it to say what Jesus must have said. Such double redaction is likely to take us further away from the original.

The procedure I advocate, then, is the simple one of exegeting each saying and parable as it stands in Greek as an honest representation of what Jesus said. Of course it is not possible to prove that Jesus said everything that is attributed to him in the gospels. We must be open to hearing the case of anyone who wishes to argue that Jesus could not have said or is unlikely to have said such and such a thing. We will need strong justification to allow "On this rock I will build my church" to stand. The notorious differences between Jesus reported discourse in the synoptics and in John will need special attention. Yet the success of a Life will in some degree be measured by how much of Jesus' teaching it makes sense of. The more that must be ignored or relegated to the early church the less likely is it that we have a viable life.

\subsection{Miracles}

The Lives of the 19th century were largely an attempt to bring Jesus within the framework of eighteenth and nineteenth-century beliefs about the nature of the universe. The triumphs of a scientific age seemed to exclude the possibility of intervention by God in any way that might disturb or compromise the natural order. Since the gospels manifestly told the story of an intervention by God, in which miracle for a while became commonplace, the story had to be rewritten in a "scientifically" and historically acceptable way.

If the miraculous is impossible, it might seem obvious that the Jesus story is so riddled with falsity that those like Reimarus and Schweitzer who debunked and disposed of it were following the only possibly course, but, as it happened, there were many who sought to salvage an essential Christianity and a non-miraculous 
Jesus as a basis for faith in their own time. The main dispute was between those who wanted to see the gospel story as essentially historical, but mistaking for miracles natural though perhaps unusual events, and those who felt the story had been deliberately clothed with the miraculous to convey the deeper feelings and beliefs of the early Christians.

It was the challenge to discover a different Jesus than the gospels portrayed that largely accounts for the incredible number of Lives that were written in the nineteenth century. Once the gospels were no longer the accepted standard for the shape of Jesus, it lay open to anyone to pick and choose what he wanted, and it is not surprising that the "Jesuses" who emerged were very much characterizations of each different writer's ideal man, and anything but the result of "scientific" historical inquiry. This licence to pick and choose in the name of "scientific history" (it is actually the reverse of what it claims to be) has continued down to the present, with the production of a Jesus to champion any and every cause from the far right to the far left, from the moral majority to the gay revolution, from pacifism to armed liberation.

Schweitzer himself was locked into the presupposition of no miracle, no divine intervention, though he is honest enough to see that for Jesus and the Jews divine intervention lay at the heart of the messianic mission. Nevertheless, his final conclusion is that God did not intervene - Jesus admitted his mistake in his cry of dereliction from the cross - the whole belief in an intervening God crashed in ruins. Thus Schweitzer reached the conclusion from which presuppositionally he began.

In the course of this century the scholarly enterprise has become increasingly aware of how bound we are by our starting assumptions. Often we do not recognize them as controlling factors in our reasoning. From this it is easy to despair and think we can never escape from our presuppositions; we are destined, as it were, to think along a particular path, and can never be sure that we are thinking truthfully, because we are so bound by our initial premises. But this is too negative and sceptical a conclusion by far.

Presuppositions can be tested, and it is important to see that one of the ways of testing them is to see how they work in actually coping with the problem in hand. It is only by working through the life of Jesus according to a certain set of understandings that one sees whether the starting point was adequate and true. Thus studies of Jesus on Marxist, or atheist, or spiritualist, or feminist or whatever principles, are to be welcomed. Most scientific advance proceeds in the manner of trying a hypothesis and seeing if it works. The vital question is whether such starting points allow themselves to make good sense of all the data we have about Jesus, and whether, it they don't, the approach can be abandoned in favour of a better one. The problem comes when data is ignored or twisted to make the hypothesis work, and this unfortunately has been a factor in some 
gospel research, as it has been from time to time in all branches of scientific research.

Though one still frequently encounters the closed universe mind-set, there is a greater reluctance in Jesus studies of the last 30 years to say that Jesus could not have done miracles. It is now commonly accepted that he must have been an exceedingly impressive exorcist. Morton Smith (1978), though he makes no Christian claims, thinks the gospels are not coherent if the miracles are subtracted; one can find no reason why people should have followed Jesus as they did. He is undoubtedly correct. If people are attracted to follow someone they will generally want to tell you why. The gospels tell us that his miracles were a great part of his attractiveness. If it was something else it is strange they do not tell.

One need make no apologies, therefore, for an approach that listens carefully to the stories of Jesus' miracle-working and exorcism and tries to understand them within the framework of his mission and strategy. Other presuppositional starting points are possible, but there is no scientific or philosophical reason to rule out this one in advance. Indeed it is not impossible that one could seek to construct a canonically-based Life without any certainty about the truth or otherwise of the miracles. The move from believing them possible to seeing them as a reality is something that may be forced upon us by the evidence of Jesus' ministry. It will be a further test of the validity of a canonically-based approach whether a Life that accepts the evangelists' testimony to Jesus' miracle working hangs together and makes more sense of everything else than one built on rationalistic or some other set of principles.

\subsection{The resurrection}

The resurrection cannot but be a watershed in approaches to the history of Jesus. More than anything else it is Schweitzer's studied ignoring of the resurrection which makes his study as fundamentally anti-Christian as that of Celsus. Jesus' cry of dereliction was his acknowledgement of God's failure to intervene, says Schweitzer. Jesus took the notion of an intervening God to its terrible conclusion and destroyed that whole worldview. But the evangelists say God did intervene - on the third day.

It was belief in the resurrection which caused people to continue to believe in Jesus after his death, write gospels, and which brought Christianity down to our times. Historians and philosophers might continue to interest themselves in a dead Jesus; most people will not. Conviction about the truth of the resurrection is the sine qua non of Christianity and thus of ongoing interest in the life of Jesus. Of course there are those who disdain the idea of resurrection, yet are passionately interested in Jesus to the point of writing books about him. That, I think, is often because he stands behind the gigantic network of people and 
institutions we call Christianity, which invites subversion at its heart. If they were to succeed in their desire to convince us he is dead, one wonders how long there would be people confessing to follow him. Once these were gone, would there be any interest in Jesus, even for the sceptic? John Dominic Crossan (1995:188) appears to relish asserting that Jesus was taken by his crucifiers and buried in a shallow grave: "Horror is history". But what is his basis for asserting this as history in the face of every single source? It is pure make-up. And who will follow his cynic peasant today? Is there any evidence that anyone ever did? I do not say that a Life without a real resurrection cannot be coherent. What we should insist, however, is that every attempted Life must allow itself to be probed as to whether it could have commanded the following it did then, even if it is indifferent to whether it might draw people today.

\subsection{A purposeful Jesus}

When 20 years ago I first began to conceive writing a Life of Jesus it was out of fascination and a sense of the need. I had no thesis about the controlling purpose of Jesus' mission. It was as my reading and writing proceeded that I first realized the importance of the question, and secondly began to have an inkling what it might be. A hypothesis may turn out to be right or wrong; it will most certainly turn out to be not the whole story. Nevertheless, I have come to think that some thesis about Jesus' aim is a necessity. Purposeless, Jesus most certainly was not. "The key to historical understanding is the grasp of intentionality" (Meyer, 1979:175).

Whether, as evangelicals tend to think, he lived and worked for the sole purpose of dying a sacrificial death, or to found the church as Catholics might see it, or to bring the Spirit, or to live an exemplary life, are questions that need to be framed as theses and tested. It is the fact that none of these alone or in combination seems to exhaust the range of his words and deeds which makes the "quest of the historical Jesus" - to give the phrase its original meaning - so intriguing and yet so important. For the believer who wishes to follow Jesus there can be hardly any more vital question than the Master's purpose. To his disciples Jesus said, "I no longer call you servants, for a servant does not know what his master is doing. I have called you my friends, because everything I have heard from my Father I have made known to you" (John 13.15). Should it not be the aim of Jesus research to reach that understanding of Jesus' mission indicated in this saying?

\subsection{Was Jesus mistaken?}

If we are going to deal with Jesus' aim, the question whether he was mistaken about the outcome of his ministry is unavoidable. According to Reimarus, Jesus was frustrated in his attempt to become Israel's political ruler. His first miscalculation in Schweitzer's reconstruction was to think that God would 
reveal him as the heavenly Son of Man before the end of the mission of the twelve; he recalculated and believed that the great denouement would come only if he was prepared to offer himself as a sacrifice for Israel. Sensing himself abandoned by God he admitted his mistakenness in his cry of dereliction. Though few have followed Schweitzer's view that Jesus expected the kingdom to come in his own lifetime, it has become a commonplace of New Testament scholarship that he expected it in the generation of his disciples. Since everyone agrees the new world did not arrive, we appear to be faced with the choice between a Jesus who mistakenly proclaimed the imminence of Israel's eschatological hope, or whose message was actually about something inward and spiritual, with no immediate implications for the transformation of the world. Is there an alternative to these conclusions? I do not think a modern Life of Jesus can avoid this problem area.

\subsection{Outcome and achievement}

It is not beyond the scope of a Life of Jesus to look in broad outline at the outcome of his ministry and particularly to inquire to what extent he intended and foresaw this. This raises Loisy's celebrated assertion that Jesus preached the kingdom and what resulted was the church - another manifestation of the thesis that Jesus was fundamentally mistaken. Meyer (1979), Sanders (1993) and Wright (1996) all argue that Jesus intended to found a community. But what meaning did he see in this community? Is the church that resulted congruent with his foundation vision? And what future did he imagine for it? And what future did he imagine for Israel? All these questions really belong to a discussion of his aims, and whether he was correct or mistaken in his expectations. Nevertheless, we can hardly consider these without a careful consideration of the actual outcome of his life and of possible still future developments.

\subsection{A tentative hypothesis}

A canonically-based Life such as I am proposing will necessarily have the nature of a tentative hypothesis. It will locate as many of the actions and teachings of Jesus within a framework, provided on the one hand by the known historical background of the times, and on the other by the author's understanding of Jesus' aims and strategies. These can only be inferred from the gospel material, and must therefore be advanced on a tentative basis. The success of the hypothesis will be judged by how much of the data provided by the canonical gospels and other background studies fits into such a life and is illuminated by it. The actual quantity of data - even in the gospels - is extensive, so false or incomplete hypotheses quickly become evident.

My own attempt at a Life has left me with a number of residual puzzles and apparent contradictions. I hesitate to solve them, either by forced harmonization, 
or by denying the dominical origin of the material. Too many times have I found with time that it was a false presupposition on my part or the lack of other essential information that caused a piece of data not to fit, or to appear contradictory. Better to leave some loose ends, I think, and admit that our reconstructions can never be more than "faith seeking an understanding of itself", at the same time as we hope that they may be effective in showing forth in clearer light "the glory of God in the face of Jesus Christ".

\section{Bibliography}

BORG, M. 1987. Jesus: A New Vision. San Francisco : Harper \& Row.

BORNKAMM, G. 1973. Jesus of Nazareth. London : Hodder \& Stoughton.

BULTMANN, R. 1931. History of the Synoptic Tradition. Oxford : Basil Blackwell.

BULTMANN, R. 1951. Jesus. Tübingen : Mohr.

BULTMANN, R. 1960. Jesus Christ and Mythology. London : SCM.

CROSSAN, J.D. 1991. The Historical Jesus: the Life of a Mediterranean Jewish Peasant.

Edinburgh : Clark.

CROSSAN, J.D. 1995. Who Killed Jesus? San Francisco : Harper.

DODD, C.H. 1932. The Framework of the Gospel Narrative. Expository Times, 43:396-400.

DODD, C.H. 1936. Parables of the Kingdom. London : Nisbet.

DODD, C.H. 1971. The Founder of Christianity. London : Collins.

FRANCE, R.T. 1975. The Man they Crucified. Leicester : IVP.

FUNK, R.W. 1996. Honest to Jesus. San Francisco : Harper Collins.

FUNK, R.W., HOOVER, R.W. \& THE JESUS SEMINAR. 1996. The Five Gospels. New York : Scribner.

HARVEY, A.E. 1982. Jesus and the Constraints of History. London : Duckworth.

HENGEL, M. 1989. The Johannine Question. London : SCM; Philadelphia : Trinity Press International.

HORSLEY, R.A. 1993. Jesus and the Spiral of Violence. Minneapolis : Fortress.

JEREMIAS, J. 1964. The Problem of the Historical Jesus. Philadelphia : Fortress. (Originally published as: The Present Position in the Controversy Concerning the Problem of the Historical Jesus. Expository Times, 69:333-339.)

KÄHLER, M. 1964 [1896]. The So-Called Historical Jesus and the Historic Biblical Christ. Philadelphia : Fortress.

KÄSEMANN, E. 1953. The Problem of the Historical Jesus. (In Käsemann, E. Essays on New Testament Themes. London : SCM. p. 15-47.)

MEIER, J.P. 1991. A Marginal Jew: Rethinking the Historical Jesus. Volume 1. New York, London : Doubleday.

MEIER, J.P. 1994. A Marginal Jew: Rethinking the Historical Jesus. Volume 2. New York, London : Doubleday.

MEYER, B. 1979. The Aims of Jesus. London : SCM.

PIKE, D.K. \& KENNEDY, R.S. 1972. The Wilderness Revolt. Garden City New York : Doubleday.

REIMARUS, Talbert, C.H., ed. 1970. Fragments. London : SCM.

RIESNER, R. 1981. Jesus als Lehrer. Tübingen : Mohr.

RIESNER, R. 1991. Jesus as Preacher and Teacher. (In Wansbrough, H., ed. Jesus and the Oral Gospel Tradition. Sheffield Academic Press. p. 185-210.)

ROBINSON, J.A.T. 1985. The Priority of John. London : SCM.

SANDERS, E.P. 1993. The Historical Figure of Jesus. London : Penguin.

SCHMIDT, K.L. 1919. Der Rahmen der Geschichte Jesu. Berlin. 
SCHWEITZER, A. 1966. My Life and Thought. London : Unwin.

SCHWEITZER, A. 1998. The Quest of the Historical Jesus. Baltimore \& London : John Hopkins University Press.

SECCOMBE, D.P. 1983. Possessions and the Poor in Luke-Acts. Linz : SNTU.

SECCOMBE, D.P. 1999. The Story of Jesus and the Missionary Strategy of Paul. (In Bolt, P.G., Thompson, M.D., eds. The Gospel for the Nations. Grand Rapids/Leicester : Baker/ IVP.)

SMITH, M. 1978. Jesus the Magician. London : Victor Gollancz.

STEIN, R. 1996. Jesus the Messiah. Downers Grove : IVP.

TAYLOR, V. 1954. The Life and Ministry of Jesus. London : Macmillan.

THEISSEN, G. \& MERZ, A. 1998. The Historical Jesus. London : SCM.

THIERING, B. 1992. Jesus and the Riddle of the Dead Sea Scrolls. San Francisco : Harper.

VERMES, G. 1973. Jesus the Jew. London : Collins.

WRIGHT, N.T. 1993. The New Testament and the People of God. London : SPCK.

WRIGHT, N.T. 1996. Jesus and the Victory of God. London : SPCK. 